Acta vet. scand. 1981, 22, 171-179.

From the State Veterinary Institute for Virus Research, Lindholm, Denmark.

\title{
VACCINATION AGAINST PORCINE PARVOVIRUS INFECTION
}

By

K. J. Sфrensen and J. Askaa

\begin{abstract}
SØRENSEN, K. J. and J. ASKAA: Vaccination against porcine parvovirus infection. Acta vet. scand. 1981, 22, 171-179. - Of 13 gilts 7 were vaccinated twice at an interval of 3 weeks with an inactivated vaccine against porcine parvovirus (PPV) infection, while the 6 nonvaccinated gilts served as controls. Starting after the 1st vaccination the gilts were bred and, after about 40 days of gestation, challenged intravenously with virulent PPV. The vaccinated gilts produced an antibody respons after the 1 st and 2 nd vaccination compatible with a primary and a secondary immune response, respectively. The nonvaccinated gilts remained low-titered or PPV antibody negative until after challenge. The gilts were killed after about 90 days of gestation, and their litters were examined. All of 53 fetuses from the vaccinated gilts were alive, and infection with PPV could not be demonstrated. Conversely, 50 of 65 fetuses from the non-vaccinated gilts were infected with PPV, and 43 were dead.

In a field study comprising 2 herds, PPV seronegative or lowtitered gilts were vaccinated before mating. There were no obvious signs of reproductive disorders in the 2 herds during the vaccination trials, and the reproductive performance of vaccinated gilts did not differ significantly from that of non-vaccinated gilts.
\end{abstract}

vaccine; porcine parvovirus; pigs.

In a recent investigation a high prevalence of infection with PPV was found among dead fetuses from Danish pig breeding herds with reproductive failure, incriminating PPV as a possible common cause of fetal death in Denmark (Sørensen \& Askaa 1981).

In order to study the possibility of preventing PPV-induced reproductive failure by vaccination, several experimental PPV vaccines have been produced and tested by measuring antibody response in pigs after vaccination (Joo \& Johnson 1977), by measuring the inhibition of viremia and viral discharge after challenge of vaccinated piglets (Suzuki \& Fujisaki 1976) and by 
measuring to what extent PPV-induced reproductive failure in pigs might be prevented by vaccination (Fujisaki et al. $1978 \mathrm{a}, \mathrm{b}$, Mengeling et al. 1979, 1980).

In the present report an inactivated PPV vaccine was tested experimentally as well as under field conditions.

\section{Experimental study}

\section{MATERIALS AND METHODS}

Gilts (Danish Landrace), which had not experienced infection with PPV as evidenced by HI-tests, were purchased from a commercial pig breeding farm.

Each of 7 gilts housed in an isolation unit were vaccinated twice at an interval of 3 weeks by subcutaneous injection of $2 \mathrm{ml}$ and $1 \mathrm{ml}$ vaccine, respectively.

The vaccine was prepared as described by Lei et al. 1980 .

Through a fence the gilts were in contact with a boar negative for HI antibody to PPV. A group of 6 gilts housed in another unit served as unvaccinated controls.

Beginning 1 week after the 1 st vaccination the gilts were bred by artificial insemination on 2 consecutive days, immediately following initial signs of estrus. Gilts failing to conceive were bred again at the next estrus. At about the 40th day of gestation the gilts were moved to another isolation unit and challenged by intravenous administration of $10^{7}$ TCID50 of virus. PPV strain 839 (Danish field strain) at the 4th passage level in primary pig kidney cells was used as the challenge virus. The gilts were killed at about the 90th day of gestation and their fetuses examined for infection.

Blood samples from the gilts were collected at the time of the 1 st and the 2 nd vaccination, 2 weeks after the 2 nd vaccination, at the time of challenge and at the time of necropsy.

\section{Field study}

In a herd (Plumrosegaarden) which had experienced reproductive failure induced by PPV, blood samples from all gilts (Danish Landrace) were examined for HI-antibody to PPV before mating. Of the seronegative or low titered gilts $90 \%$ were vaccinated before mating as described above, while $10 \%$ served as controls. Blood samples of vaccinated and non-vaccinated gilts were collected simultaneously before the 1 st vaccination and 
$7-12$ weeks after the 2 nd vaccination. The reproductive performance, i.e. number of matings, number of live and dead piglets per litter of vaccinated and non-vaccinated gilts, including those, which had acquired active immunity before mating, was recorded.

In a second herd (Sams $\varnothing$ farmen), newly established by purchasing gilts (Danish Landrace and Danish Landrace-Yorkshire crossings), $50 \%$ of the gilts. were vaccinated twice immediately after installation according to the above-mentioned vaccination scheme, i.e. before or at about the start of breeding. Blood samples from about $25 \%$ of the vaccinated and non-vaccinated gilts were collected simultaneously before the 1 st vaccination and 2 weeks after the 2 nd vaccination. The reproductive performance of vaccinated and non-vaccinated gilts was recorded.

\section{Laboratory tests}

Isolation of PPV from fetal tissues and demonstration of antibody against PPV in fetal fluids was performed as described elsewhere (Sфrensen \& Askaa 1981). Sera from the gilts were examined for antibody to PPV using the hemagglutination inhibition (HI) test (Joo et al. 1975).

\section{Experimental study}

\section{RESULTS}

Only minor local reactions at the sites of vaccination were observed. The gilts produced low levels of antibody to PPV after the 1st vaccination followed by an increase after the 2nd vaccination (Table 1). At the time of challenge a decrease of the titers had occurred. The boar kept in contact with the vaccinated gilts remained seronegative throughout the period. The non-vaccinated gilts remained low-titered or negative for antibody to PPV until after challenge (Table 1). In none of the 53 live fetuses of the 7 vaccinated gilts could infection with $P P V$ be demonstrated (Table 2). Conversely, 50 of 65 fetuses of the non-vaccinated gilts were infected and 43 were dead. Transplacental infection had apparently not occurred in 1 non-vaccinated gilt, where all 12 fetuses were alive and none infected with PPV. The average litter size of the vaccinated gilts was smaller than that of the non-vaccinated gilts. The average number of corpora lutea was identical for vaccinated and non-vaccinated gilts. 
T a ble 1. Antibody development following vaccination with a PPV vaccine and subsequent challenge with virulent $P P V$.

\begin{tabular}{lcrrrrr}
\hline $\begin{array}{l}\text { Gilt } \\
\text { No. }\end{array}$ & $\begin{array}{l}\text { Vacci- } \\
\text { nated }\end{array}$ & \begin{tabular}{c}
\multicolumn{5}{c}{ Titer values } \\
nat 1st \\
vacci- \\
nation
\end{tabular} & $\begin{array}{c}\text { at 2nd } \\
\text { vacci- } \\
\text { nation }\end{array}$ & $\begin{array}{c}\text { 2 weeks } \\
\text { after 2nd } \\
\text { vaccination }\end{array}$ & $\begin{array}{c}\text { at } \\
\text { challenge }\end{array}$ & $\begin{array}{c}\text { at } \\
\text { necropsy }\end{array}$ \\
\hline 1598 & - & 16 & - & - & 16 & 4096 \\
1599 & - & $<8$ & - & - & $<8$ & 2048 \\
1773 & - & 16 & - & - & $<8$ & 2048 \\
1618 & - & $<8$ & - & - & $<8$ & 1024 \\
1619 & - & 16 & - & - & $<8$ & 2048 \\
1605 & - & 16 & - & - & 16 & 2048 \\
1580 & + & $<8$ & 64 & 512 & 256 & 256 \\
1917 & + & $<8$ & 64 & 1024 & 256 & 512 \\
1880 & + & $<8$ & 64 & 512 & 512 & 512 \\
1596 & + & $<8$ & 64 & 512 & 128 & 512 \\
1899 & + & $<8$ & 64 & 128 & 64 & 512 \\
1757 & + & 16 & 128 & 1024 & 256 & 1024 \\
1647 & + & $<8$ & 64 & 1024 & 256 & 2048 \\
\hline
\end{tabular}

Except for the gilt where transplacental infection apparently had not occurred (No. 1618), PPV was easily isolated from all dead fetuses of the non-vaccinated gilts and from all but 5 live fetuses, 2 of which had antibody to PPV (Table 3). In fetuses with crown-rump measures $\geq 12 \mathrm{~cm}$ antibody to PPV was demonstrated in all but 8 dead and 4 live fetuses. In 3 live fetuses neither PPV nor antibody to PPV was found.

T a b l e 2. Prevention of reproductive failure by vaccination with a PPV vaccine.

\begin{tabular}{lcc}
\hline & Vaccinated & Non-vaccinated \\
\hline Number of gilts & 7 & 6 \\
Number of fetuses, total & 53 & 65 \\
Infected fetuses & 0 & 50 \\
Dead fetuses & 0 & 43 \\
Fetuses per litter, mean & $7.6^{1}$ & $10.8^{2}$ \\
Corpora lutea per litter, mean & $14^{3}$ & $14^{3}$ \\
\hline
\end{tabular}

$1 \mathrm{~s}=2.2$, range: $5-11$

$2 \mathrm{~s}=3.9$, range: $6-15$

$3 \mathrm{~s}=1.5$, range: $12-16$ 


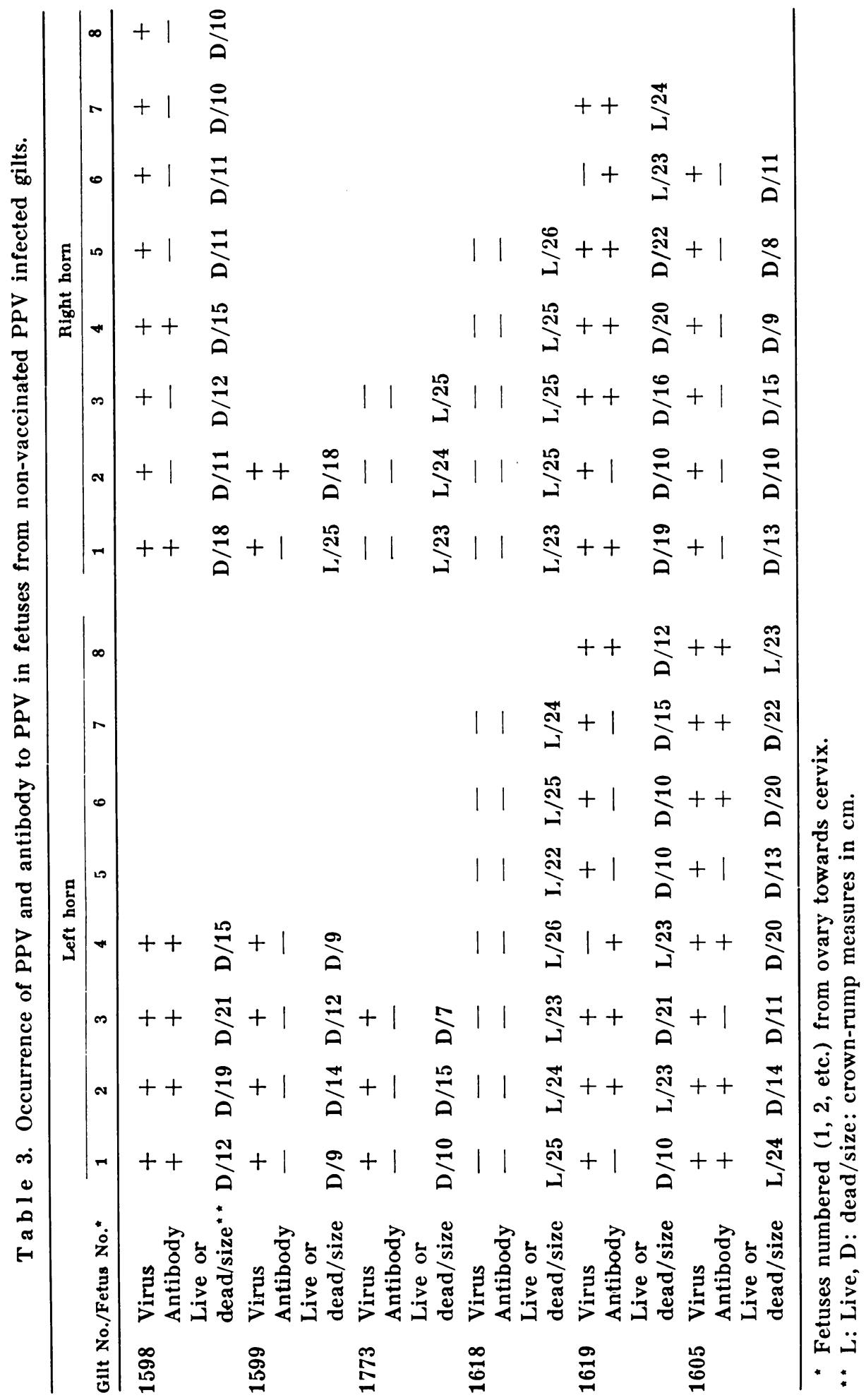


T a ble 4. Antibody titers to PPV before and 7-12 weeks after the vaccination trial ("Plumrosegaarden" $1979-80$ ).

\begin{tabular}{lrrrrr}
\hline & $\begin{array}{c}\text { Total } \\
\text { number }\end{array}$ & \multicolumn{4}{c}{ HI-titers } \\
\cline { 3 - 6 } & & $<32$ & $64-256$ & $512-1024$ & $>1024$ \\
\hline Gilts before vaccination & 364 & $304(84 \%)$ & $60(16 \%)$ & 0 & 0 \\
Vaccinated gilts & 324 & $16(5 \%)$ & $124(38 \%)$ & $127(39 \%)$ & $57(18 \%)$ \\
Non-vaccinated gilts & 40 & $28(70 \%)$ & $6(15 \%)$ & $3(8 \%)$ & $3(8 \%)$ \\
\hline
\end{tabular}

\section{Field study}

The majority $(77 \%)$ of the vaccinated gilts at Plumrosegaarden had developed HI-antibody titers in the range 64-1024 from $7-12$ weeks after the 2nd vaccination, while $18 \%$ developed HI-titers $>1024$ (Table 4). A few animals (5\%) did not respond to the vaccination with an increase of antibody titer. Of the non-vaccinated gilts $70 \%$ remained low titered or seronegative. The reproductive performance of the vaccinated group and of the group, which had acquired immunity due to infection with PPV before mating, were equal with respect to number of matings, number of live piglets and number of dead piglets per litter (Table 5). The non-vaccinated antibody negative group farrowed about 1 live piglet less per litter than the vaccinated group. The difference, however, was not statistically significant (Student's t-test).

At Sams $\phi$ farmen 147 of 286 gilts were vaccinated. Among 37 vaccinated gilts $84 \%$ developed HI-titers $\geq 512$, whereas $16 \%$ developed titers ranging from $64-256$ (Table 6). Of 39 non-

Table 5. The reproductive performance of vaccinated and nonvaccinated gilts ("Plumrosegaarden" 1979).

\begin{tabular}{lcccc}
\hline $\begin{array}{l}\text { Animals grouped } \\
\text { before mating }\end{array}$ & $\begin{array}{c}\text { Number } \\
\text { of } \\
\text { litters }\end{array}$ & $\begin{array}{c}\text { Matings } \\
\text { per litter, } \\
\text { mean }\end{array}$ & $\begin{array}{c}\text { Live piglets } \\
\text { per litter, } \\
\text { mean }\end{array}$ & $\begin{array}{c}\text { Dead piglets } \\
\text { per litter, } \\
\text { mean }\end{array}$ \\
\hline $\begin{array}{l}\text { PPV antibody negative and } \\
\text { subsequently vaccinated }\end{array}$ & 161 & 1.3 & 8.5 & 0.7 \\
$\begin{array}{l}\text { PPV antibody negative } \\
\text { non-vaccinated }\end{array}$ & 25 & 1.4 & 7.6 & 0.5 \\
$\begin{array}{l}\text { PPV antibody positive } \\
\text { non-vaccinated }\end{array}$ & 110 & 1.4 & 8.6 & 0.7 \\
\hline
\end{tabular}


T a b l e 6. Antibody titers to PPV before and about 2 weeks after the vaccination trial ("Samsøfarmen" 1979).

\begin{tabular}{lcrrrr}
\hline & $\begin{array}{c}\text { Total } \\
\text { number }\end{array}$ & \multicolumn{4}{c}{ HI-titers } \\
\cline { 3 - 6 } & & $<32$ & $64-256$ & $512--1024$ & $>1024$ \\
\hline Gilts before vaccination & 76 & $66(87 \%)$ & $6(8 \%)$ & $1(1 \%)$ & $3(4 \%)$ \\
Vaccinated gilts & 37 & $0(0 \%)$ & $6(16 \%)$ & $17(46 \%)$ & $14(38 \%)$ \\
Non-vaccinated gilts & 39 & $29(74 \%)$ & $6(15 \%)$ & $2(5 \%)$ & $2(5 \%)$ \\
\hline
\end{tabular}

vaccinated gilts $74 \%$ remained low-titered or seronegative. The vaccinated group farrowed 0.5 live piglets more per litter than the non-vaccinated group. The difference, however, was not statistically significant (Student's t-test) (Table 7).

Table 7. The reproductive performance of vaccinated and nonvaccinated gilts ("Sams $\varnothing$ farmen" 1979).

\begin{tabular}{lcccc}
\hline $\begin{array}{l}\text { Animals grouped } \\
\text { before mating }\end{array}$ & $\begin{array}{c}\text { Number } \\
\text { of } \\
\text { litters }\end{array}$ & $\begin{array}{c}\text { Matings } \\
\text { per litter, } \\
\text { mean }\end{array}$ & $\begin{array}{c}\text { Live piglets } \\
\text { per litter, } \\
\text { mean }\end{array}$ & $\begin{array}{c}\text { Dead piglets } \\
\text { per litter, } \\
\text { mean }\end{array}$ \\
\hline Vaccinated gilts & 147 & 1.2 & 9.3 & 0.9 \\
Non-vaccinated gilts & 139 & 1.3 & 8.8 & 0.7 \\
\hline
\end{tabular}

\section{DISCUSSION}

In the experimental study the vaccinated animals developed an antibody response after the 1 st and the 2 nd vaccination with an inactivated PPV-vaccine, compatible with a primary and a secondary immune response, respectively. Joo \& Johnson (1977) obtained a similar antibody response after vaccination twice with a formalinized-gel vaccine, while Mengeling et al. (1979) did not observe a clear effect of the 2nd vaccination using an acetylethyleneimine inactivated vaccine. The reason for this difference is not immediately apparent.

Although the 2- to 8-fold increase of HI-titer after challenge in 5 of the 7 vaccinated gilts might indicate replication of the challenge virus, transplacental infection and fetal death did not occur.

The reasons for the lower average number of fetuses in the vaccinated group than in the non-vaccinated group is not clear. Therefore the question of whether the vaccine interfered with conception and embryonic development could arise. In the field 
study comprising vaccination trials in 2 different herds, such an effect on reproductive performance was, however, not observed, indicating absence of reproductive disorders during the vaccination trials. All vaccinated animals tested in the one herd, and all but $5 \%$ of the vaccinated in the other herd responded to the vaccination by production of $\mathrm{HI}$-antibodies. The lack of response to the vaccination in a few animals was explained by occurrence of residual maternal antibody at the time of vaccination.

In conclusion it was established that vaccination of gilts with this PPV vaccine induced production of $\mathrm{HI}$-antibodies and prevented the occurrence of experimental transplacental infection and fetal death. Adverse effects of the vaccination were not observed.

\section{ACKNOWLEDGEMENT}

The excellent technical assistance of Mrs. Irene Houmann Poulsen and Mrs. Marianne Berglund is highly appreciated.

\section{REFERENCES}

Fujisaki, Y., Y. Watanabe, K. Kodama, H. Hamada, Y. Murakami, T. Sugimori \& J. Sasahara: Protection of swine with inactivated porcine parvovirus vaccine from fetal infection. Bull. nat. Inst. Anim. Hlth 1978 a, 77, 9-11.

Fujisaki, Y., T. Ichikara, N. Sasaki, F. Shimizu, Y. Murakami, T. Sugimori \& J. Sasahara: Field trials on inactivated porcine parvovirus vaccine for the prevention of viral stillbirth among swine. Bull. nat. Inst. Anim. Hith 1978 b, 77, 12-14.

Joo, H. S., C. R. Donaldson-Wood \& R. H. Johnson: A microneutralization test for the assay of porcine parvovirus antibody. Arch. Virol. 1975, 47, 337-341.

Joo, H. S. \& R. H. Johnson: Serological responses in pigs vaccinated with inactivated porcine parvovirus. Aust. vet. J. 1977, 53, $550-552$.

Lei, J. C., E. Overby, M. Holm Jensen \& F. O. Sørensen: Preparation of a porcine parvovirus vaccine. Proc. Int. Pig. Vet. Soc. Congr., Copenhagen 1980 , p. 64.

Mengeling, W. L., T. T. Brown, P. S. Paul \& D. E. Gutekunst: Efficacy of an inactivated virus vaccine for prevention of porcine parvovirus-induced reproductive failure. Amer. J. vet. Res. 1979, 40, 204-207.

Mengeling, W. L., P. S. Paul, D. E. Gutekunst, E. C. Pirtle \& T. T. Brown: Vaccination for reproductive failure caused by porcine parvovirus. Proc. Int. Pig Vet. Soc. Congr., Copenhagen 1980, p. 61. 
Suzuki, H. \& Y. Fujisaki: Immunizing effects of inactivated porcine parvovirus vaccine on piglets. Bull. nat. Inst. Anim. Hlth 1976, 72, 17-23.

Sørensen, K. J. \& J. Askaa: Fetal infection with porcine parvovirus in herds with reproductive failure. Acta vet. scand. 1981, 22, $162-170$.

\section{SAMMENDRAG}

Vaccination mod infektion med porcint parvovirus.

Af 13 gylte blev 7 vaccineret 2 gange med 3 ugers mellemrum med en inaktiveret vaccine mod infektion med porcint parvovirus (PPV), medens 6 kontroldyr ikke blev vaccineret. Løbning af gyltene påbegyndtes efter 1 . vaccination, og ornkring 40. drægtighedsdag blev de podet intraven $\varnothing$ st med PPV. De vaccinerede gylte gav et lavt antistofsvar efter 1. vaccination efterfulgt af en udtalt stigning efter 2. vaccination. De ikke-vaccinerede gylte forblev lavtitrede eller negative for PPV antistof til efter podning. Gyltene blev aflivet omkring 90 . drægtighedsdag, og fostrene blev unders $\varnothing$ gt. Alle 53 fostre fra de 7 vaccinerede gylte var i live og ikke inficeret med PPV. Derimod var 50 af 65 fostre fra de 6 ikke-vaccinerede gylte inficeret med PPV, og 43 var døde.

I 2 besætninger blev PPV seronegative eller lavtitrede gylte vaccineret før løbning. Der var ingen synlige tegn på reproduktionsforstyrrelser $\mathrm{i}$ vaccinationsperioden og reproduktionsresultaterne blandt vaccinerede og ikke-vaccinerede gylte fandtes ikke signifikant forskellige.

(Received December 19, 1980).

Reprints may be requested from: K. J. Sørensen, the State Veterinary Institute for Virus Research, Lindholm, DK-4771 Kalvehave, Denmark. 